DOI: doi.org/10.21009/IJLECR.071.10

Received: 21 July 2020

Revised: 21 December 2020

Accepted: 18 June 2021

Published: 30 June 2021

\title{
INTEGRITY OF BILINGUAL ABILITY OF WRITING AND READING SOCIETY OF JAVA CIREBON
}

\author{
Rina Nuryani ${ }^{1, \mathrm{a})}$ \\ STKIP Muhammadiyah Bogor ${ }^{1)}$ \\ rinanoeryanii@gmail.com ${ }^{\text {a) }}$
}

\begin{abstract}
Language is studied by humans differently based on the environment in which they are located, so that languages around the world are very diverse. This is because culture, condition, geography, and nature are different between one group of human beings and the others from one place to anothercommunity. Itis known in SindangJawa Cirebon Village that the society in RW 1 (KampungPontas) alongwith RW 2, 3, 4, and 5, agreed to express the real reason why people from KampungPontas who use Javanese language astheir mother language have difficulty in using Sundanese, unlike those in RW 2, 3, 4, and 5 that are generally fluent in Javanese. In the opinion of both people said that the words in Sundanese often use the phoneme "eu", which makes people said Pontas that in fact the Javanese become lazy and difficult in usingSundanese language. The researcher concluded that the lackof ability in these two language skills ultimately influenced the level of bilingual and multilingual capabilities of the community in Pontas Village.
\end{abstract}

Keywords: Language, Bilingual, Writing Ability, Reading Ability, Sociolinguistics

Language is a human tool in order to communicate with other humans in life. Language is what we want to convey to others in the form of verbal and non verbal. Therefore, every human being is able to live their lives with other human beings normally requires a tool that can bridge their interests through a communication tool called language.

As Poerwadarminta (2006: 80) explains that "language: 1) is a symbolic system that people use to create thoughts and feelings: extend knowledge, 2) words spoken by a nation (ethnicity, state, etc.)". therefore, it is clear that language also makes peopleto be able to expand their knowledge.

Language is studied by humans differently based on the environment in which they are located, so that languages around the world are very diverse. This is because the culture, condition, geography, and nature are different between one group of people with theothers from one place to another. However, the thing that unites humans all over the places in this earth in various interests with other human groups is certainly the language.

To pursue his interests with other groups or nations, man can not stand idly by a single language as a means of communication he possesses. Man needs to learn and master other languages outside his mother tongue. Man can not develop his life if they only rely on the ability of using one language. Therefore, in his life man can not be separated from the need for wisdom.

Today's bilingualism has taken place in modern societies that have more intercultural language in communicating with other nations. However, bilingualism can also occur in traditional societies. 
As in the community of SindangJawa Village, DukuPuntangSubdistrict of Cirebon Regency, an area with unique characteristic and based on community differences, it turns out that one of the two villages has bilingual and even multilingual capability. It is said thatthe area of this village is $211,998 \mathrm{Ha}$. It is in the north bordering DepokCity, in the east bordering KenangurahanKenanga, in the south ofSumberSidawangi Village, and bordered by Cisaat Village.

The uniqueness of the most distinct in the language of the local community (native) SindangJawayang has its own story. In everyday life, they use two or even three different languagesnamely Sundanese Cirebon, Javanese language Cirebon, and Bahasa Indonesia. The uniqueness actually originated from the existence of a group of migrant communities (RW 1) in Sindang Java that still use the Central Java language as the mother tongue (first language) in their daily life. While the surrounding villages which are natives of SindangJawa (RW 2, 3, 4, 5) are even more adaptable to the Central Java language when meeting with people from RW 1 whose origins are migrants.

The territory of the migrants referred to their territory as Pontas Village, whereas for indigenous communities there were RW 2, 3, 4, and 5.The names of the "Pontas Village" are due to their location to be located across the river separated from the other villages of RW 2, 3, 4, and 5 . The word Pontas itself actually originated from the Sundanese language that originated from the word peuntas which means "across". Since the Javanese in the area can not pronounce the Sundanese phoneme /eu/, the word peuntas becomes pontas.

The uniqueness of the language ultimately enriches to the richness of language in the region in the form of bilingual and multilingual, especially for indigenous communities in RW 2, 3, 4 and 5 regions in the language of Sundanese, Javanese and Indonesian. While in RW 1 or in the village only a few people can use two language, those are Java and Indonesian language.

Communities in RW 2, 3, 4, and 5, use Sundanese as their mother tongue, while the Javanese and Indonesian languagesthey speak are used as the language of instruction in schools and in the community when they have to communicate with people from outside Sindang Java, with people from KampungPontas.

Although in general, people in KampungPontascannot speak Sundanese and are more persistent with their mother tongue, while at school and outside Pontas Village, they prefer to use Bahasa Indonesiaas the language of instruction. In fact, the elementary school located in Pontas Village is more dominant in the use of Javanese language as the instructional language of teachingand learning activity. This is known by a direct interview with the Pontas Village childnamed Fadlig (11), when he was playing with his friends in the courtyard of his house.

Other children say the same thing that they still find it difficult to use BahasaIndonesia in school during the lesson. According to them, they can only understand Bahasa Indonesia to the extent of their teacher's narration. Moreover, they find it difficult to say something in BahasaIndonesia. The language situation of Bahasa Indonesia that occurs in the children of Pontas Village is categorized as passive bilingualism or as the lowest language skills, because their ability in usingBahasa Indonesia just in the ability to read and write.

As Diebold and Hougen said, that ability can be a fully passive literacy reading (see A. Richard Diebold Jr., in Hymes (ed.), 1964: 495). Haugen then put forward the passive bilingual, that is, they who understands without being able to speak (Rusyana, 1988: 3).

It is also argued by Mckay (2009: 421) on fourtheologies related to social context, among others: (1) as collaborative practice, (2) as well as the reflection of the values of society and about how to approach writing, (3) as reflections of values and traditions of writings and developers; reflecting social relationships as a vehicle for changing circumstances.

In this case, the uniqueness of the region and the uniqueness of the language owned by the village of Sindang Java, encourage researcher to conduct a language research in this area. It is 
because the researcher findsout that Sindang Jaw has an association with what Mckey says about language in a region or region, especially the situation of the native in SindangJawa which is essentially related to socio-cultural factors in the region.

As Mckay (2009) points out, the skills of reading and writing are a complex one amongst both individuals and social knowledge. Therefore, this research will emphasize on how the culture of a society, especially the culture of the SindangJawa community in reading and writing ability, influenced by social context in this area. The social context in this case includes science, politics, economy, social, and culture in SindangJawa Village.

What the researcher will investigate is not only about the social context that is related to the ability to read and write, but also the most important is the relationship between the ability to read and write with the level of bilingual ability owned by the people of SindangJawa Village. On the basis of these problems, researcheris interested to conduct a qualitative study of analytical techniques entitled "Intensity of Bilingual Use of Ability to Write and Read Society Sindang Java Cirebon".

\section{METHOD}

The method of research according to Syamsuddin and Damaianti (2006: 14) "is a method of solving the problem of research carried out in a planned and meticulous with the intent of obtaining facts and conclusions in order to understand, explain, maramalkan and control the situation. Method is also a way of working to understand and deepen the object being targeted ". Through the research method that has been planned, it is expected from this research obtained problem solving for the field of sociolinguistics that examines the issue of bilingual in Sindang Java Village Cirebon.

To know the influence of bilingual on the ability of reading and writing community in Sindang Java, in this study researcherused descriptive research method of analysis. This descriptive research is intended to describe the underlying symptoms and that arise because of the influence between the problems that one against other problems. As Rachmat (1991: 24) says, "descriptive research only describes the situation or event. This study did not seek or explain the relationship, did not test the hypothesis or make predictions ".

But in this analysis, the author will see the influence between the ability to write and read with the level of bilingual use of Sindang Java community, as well as social factors that background the two variables without using experimental research. Researchers will only conduct a simple study by connecting the two variables by just looking at and noticing the symptoms caused by both. As revealed by Suherli (2007: 88) that "in the paper the type of paper or article, the research method part is just peeled, as a way dish researchers do the study ... ".

This research uses interview technique, observation technique, and recording technique according to research requirement. However, the researcher did not include a written test of the SindangJawa community in terms of writing and reading skills due to time constraints, which the study conducted one day on Sunday (24/12/13). Then the researcher did not have time to do the test of writing and reading to the students in SindangJawakarena Village research conducted on Sunday and not on the days of the effectiveness of learning in school.

In obtaining sufficiently accurate data about the ability to write and read the community of Sindang Java in general, researchers took the initiative to dig the data by conducting an interview to one of the subjects of language and literature teacher of Sindang Java society. The author deliberately chose an Indonesian teacher who has long taught and know the situation and condition of writing and reading ability of society Sindang Java in the last few decades ini.Data writer dig from the teacher is information about the development of reading and writing ability in Sindang Java in general and students in Sindang Java in particular.

Observations were made on the population of SindangJawa community with a sample of 
research of children and adults who had been encountered by researchers accidentally in five RWs. In carrying out the observations, the researchers brought a handheld recording device hidden in a clothing pocket that worked to record their conversation, without them realizing that their statement was being recorded. Data from observations were obtained by observing and intercepting their conversation.

In this study, the author focused on observation research subjects. In this case, researcherobserved the ability to write and read the community with the connection to the bilingual use of SindangJawa community based on the background of the social context that occurred in the community.

\section{RESULTS AND DISCUSSION}

Researcher carried out a research in a Village of Sindang Java Cirebon on Sunday, December 23, 2017 in the condition of the sky is quite bright, precisely at 10:00 pm. In a group of researchers with fellow researchers conducted a search data by tracing the paths in RW 1, 2, 3, 4, and 5 villages.

At the time of encountering the research data, each dispersed and search of data individually byusing data seeker. A data seeker that has been prepared in the form of a small recorder or recorded in a mobile phone, and handycam directed to the data source but located in a hidden place or manipulated as if theconversation was not being recorded, so that the informant does not feel that he is being researched.

To obtain the data source, I observe the village of SindangJawa RW 1 which is located adjacent to our lodging. In this place, the researcherhad a chat with one of the originalpeople of this village named Mr. Juhari. He is a sports teacher at SindangJawa Junior High School. However, he recounts his life experiences that ventured for decades to various regions, especially in the priangan area. From these adventurous results, he has multilingual capabilities such as Bahasa Indonesia,Sundanese, and Javanese. For the Sundanese fine, he got for seven years when he taughtin pesantren in Singaparna,Tasikmalaya.

In this conversation,I watched and listened to how the cadets were transfers between Pak Juhari and the researcher. In communication with Pak Juhari, theresearcher uses SundanesePantura, using Sundanese language, Javanese, and Indonesian. Although each question researchers use different languages, but answered smoothly by Mr. Juhari without any constraints.

As our friend asked by using SundanesePantura, he will respond with Sundanese Pantura. When one of our friends spoke in Indonesian, he spontaneously answered it in Indonesian. Similarly, when one of our friends asked in Javanese, he also asked questions in Javanese. What is more surprising when the researcher asked him something with a subtle Sundanese, it was able to answer with Sundanese language fine. This I did to know the truth of his confession that he had traveled for seven years in SingaparnaTasikmalaya.

When we estaphetically asked questions through the language we mastered, it turned out that he was passing it code. A uniqueness of the difficult words we get in Sindang Java. For example, in words with the phrase, "from my name was Johar, pokokna until now namasayamahanggerJohar,". The word here in Indonesian means "fixed". Then in the sentence there is a Sundanese parole na and mah. His conversation in Indonesian and Sundanese language accompanied by the Javanese dialect cirikhas, but the Javanese language he uses more to the Sundanese dialect, in the sense of a word unlike a native Javanese who uses his language condensed (medok).

Talking about the history of naming Sindang Java, according to Mr. Juhari, this name is taken based on local community stories. This story is hereditary from the ancestors. He said that in the days of the Majapahit kingdom, the Majapahit people had made a visit to Galuh Kingdom. 
When passing through this area, they travel to rest in this area, so finally this area by them is named "SindangJawa". Sindang word means "to visit".

According to Mr. Juhari, the mother tongue used here, in RW 2, 3, 4, and 5, is the Sundanese Cirebon. While in RW 1 called KampungPontas, 90\% of the people use Javanese language. However, these two different areas of mother tongue can live in harmony and respect each other.

That place was named with KampungPontas because the area is on the other side of the river and must pass a bridge as a link to the area. However, people in RW 2, 3, 4, and 5 whose mother language is Sundanese can actually master the Javanese language as the medium of instruction when the two communities meet and communicate. On the other hand, it is different with the people of KampungPontas (RW 1), they are very difficult to speak Sundanese, so that when meeting with people from RW 2,3, 4, and 5, prefer to stay with his mother tongue (Javanese) or use Indonesian .

Both sections of the community agreed to put forward the reason why the people of Kampung Pontas get difficulty to speak in Sundanese. Unlike people from across the Pontas Village who have ease in using the Javanese language. This is because the words in Sundanese use the phoneme "eu", so the Javanese in Pontas Village can not mention the words in Sundanese such as peuntas, kajeun, meuren, hideung, etc .. For example when it comes to mentioning "KampungPeuntas", they can not name it according to Sundanese greeting, so in the end they can only say "KampungPontas". This is what makes people said in Villages Pontas feel difficult difficult so lazy to learn Sundanese. Such a situation made the people of Pontas Village only capable as passive dwibahasawan, as Diebold expressed about passive Dwibahasawanie those who understand other languages without speaking.

Another case with the public said as in RW 2, 3, 4, and 5 that can tolerate the community with Pontas Village. They want to follow and learn the Javanese language to be able to communicate with people from KampungPontas. Hence, the phenomenon of the wealth of the more controlled language of the community residing in the RW 2.3, 4, and 5. The community groups in the four RWs, in Diebold's view is said to be 'active dwibahasawan'.

The inability to use Sundanese as a secondary language in Pontas Village, according to researchers, is more common in primary school-aged children (nursery children). However, in adult speakers, their Sundanese language skills begin to be trained even with non-fluent language skills.

Based on the observation of the researcher, Sundanese language ability in adult speakers in Pontas Village society is more due to time process. Like adult speakers who start often traveling outside Pontas Village, the activity of monitor, and the marriage among the pontas with people who come from outside the pontas so that causing the ruling of other languagestaught by their spouses. This could lead to the growth of the Sundanese language in Pontas Village.

In recent years, there are also parents who come from outside Pontas Village who teach Sundanese to their children at home as their native language. However, the language most dominated and favored by the four regions in SindangJawa is Indonesian. Because this language is the language of instruction which is considered the easiest by the four areas to communicate with anyone, anytime, and anywhere.

The multilingual character in SindangJawa, which occurs between Sundanese, Javanese and Indonesian, ultimately gives birth to a coded code, coding, diglossia, parol, dialect, and typical local idiolects. Coding other than in adults such as Pak Juhari, there is also a child speakers in Pontas Village. When talking with their friends they use the Javanese language, but when spoken to in Indonesian they transfer the conversation into Indonesian language. The incident like this is not much different from the children who are in the village of Sindang Java in RW 2, 3, 4, and 5 The only difference between the people of KampungPontas and the people in the four RWs was in the 
number of languages they were able to master.

The introductory language of elementary school in KampungPontas from the teacher to the students still often uses the Javanese language. Occasionally used Indonesian language in formal situations, such as speeches at the flag ceremony. Meanwhile, Sundanese is taught as one of the local content in schools in SindangJawa. According to Nita (9), grade 4 elementary school who had encountered researchers when buying food at the stall said that the children of KampungPontas on average do not speak Sundanese despite being taught in school. To carry out the test of local language, the problems in the Sundanese language are often translated into Bahasa Indonesia by the teacher.

In accordance with what Pak Johar said that the difficulties of the children of Kampung Pontas in learning Sundanese related to the many words in Sundanese that use phoneme "eu"with the phoneme equation "e". Their tongues (children) are still rigid to pronounce the words of the Sundanese phrase "eu". But there was a small part of the Pontas Villain who was able to communicate with Sundanese when talking with researchers. Sundanese language they use is still thick with the dialect of Java. They acknowledge it is difficult to speak Sundanese and do it in a forced state, that is when meeting with people from outside the village of Sindang Java or meet with people who are not from Cirebon.

When the researcher met IbuRukan, having a food stall, one of the villagers of Kampung Pontas, revealed that in fact a small number of people in his kampungnnya began to understand and could use Sundanese. According to him Sundanese language skills they are due to the factors of marriage, work, and children who start schooling in junior high, high school and university. Marriage with the Sundanese makes a mixture of language and education of Sundanese from one parent to his son, husband to his wife or vice versa. Some Pontasresidents who worked in the villages across, especially those who became farm laborers, began to understand and understand Sundanese although listening. The existence of children who started studying outside the village of Pontas, and still in the Sindang Java region, making them to get to know and learn Sundanese.

Unlike the existing primary schools in RW 2, 3, 4, and 5, the language of instruction for teachers to students in any lesson using Indonesian language. Sundanese even though it is a local content subject, it does not dominate in any learning. For children in RW 2, 3, 4, and 5, Sundanese is a colloquial language, so in the classroom learning the children do not have difficulty in studying this one subject. However, it is unique that children in these four RWs can speak Javanese languages even though they are not as adult as they speak Javanese. This is because they are getting used to being multilingual in their schools, used to talking Java and playing with their friends from Pontas Village.

The circumstances of the SindangJawa Village community associated with these lingo, according to Diebold and Haugen are categorized to the active and passive bilingualism. The passive bilingualism were identified in the community of KampungPontas (RW 1). The naming of the passive bilingualism is as the lowest ability for a bilingual speaker. Those who are passive bilinguals can only understand a second or a third language but do not have the ability to pronounce it, or when speaking it is not as fluent as the first language / mother tongue.

What is experienced by passive bilingualism because of their lack of ability to recite Sundanese and only able to read and write, in addition to other factors such as social factors around it. Such a situation by Diebold (in Rusyana 1988: 2) is termed in incipient bilingualism. According to his opinion,

"If this initial bilingualism is excluded from the study, we ignore the early stage of language learning, whereas precisely this inter-linking identification begins, and greatly affects subsequent interference. Therefore, he proposed a change in the definition of the lowest ability for bilinguals as contact with models that may exist in the second language and the 
ability to use them in the first language environment. It can be read literary skills or fully passive abilities (libat A. Richard Diebold JR. in Hymes (ed.) 1964: 495)... Haugen then put forward the passive wisdom of understanding without speaking".

For what Diebold and Haugen above, itcan be known that the linguistic situation that occurred in Pontas Village in general is passive bilingual. While the linguistic situation found in the other four areas as in RW 2, 3, 4, and 5 is generally included in the active bilingual.

The authors' belief, the existence of active dwibahasawan and passive dwibahasawan in SindangJawa is reinforced by the latest data obtained by the authors interviewed Mr. DuanMuwardi (28), an Indonesian teacher who teaches at SMP SindangJawa and MTs.Cisaat. The two junior high schools are located in an area adjacent to SindangJawa Village. However, SMP SindangJawa is located in SindangMekar region, while MTs.Cisaat is in SindangJawa area. Pak Duan teaches Indonesian students to his students for eight years in SindangJawa Junior High School, and for the past four years. Cisaat.

The data that can be extracted from Pak Duan is expected to reveal the veil about the background and the bilingual situation that occurred in the community of SindangJawa Village. The authors in obtaining the data wanted to know many factors and background of diversity ability and level of bilingual use of SindangJawa community from RW 1 (KampungPontas) to RW2, 3, 4, and 5 .

Based on his remarks that most students from Pontas Village prefer to go to junior high school SindangJawa located in SindangMekar region, whereas most of the students who come from RW 2, 3, 4, and 5 choose to attend school in MTs.Cisaat located in SindangJawa area. According to him almost all children who come from RW 2, 3, 4, and 5 school in MTs.Cisaat because the location is closer to where they live, whereas children who come from KampungPontas (RW 1), more in junior high school Sindang Java, it is because the location of SMP Sindang Java closer to KampungPontas.

When the researcher asked about how the development of reading and writing community competence in five areas in SindangJawa Village. Pak Duan said that junior high school students of SindangJawa based on annual evaluation reduced their ability to write and read. They have a slow development of skills in terms of language skills.

Because of their Javanese background with their parents' low level of education, it makes it very difficult for them to accept any progress, including in terms of reading and writing. Plus the quality of SDMpara teachers in Sindang Java Junior High is still low. Although in SindangJawa has 3 teachers, but they are less able to membelajarkan students well in learning Indonesian. In addition, school management systems and school coaching are not good for students. While in MTs.Cisaat with students from RW 2, 3, 4, and 5 have a better development in learning Indonesian language including the ability to read and write. This is because the residents of RW 2, 3, 4, and 5 belong to the category of educated citizens with good quality teachers.

According to Pak Duan's observation that the students at SMP SindangJawa who came from Pontas Village basically have a hereditary culture from their parents that since childhood they have to help the family economy. Many of them at the age of primary school help their parents to sell, go to the rice fields, or work in the craft of furniture owned by their parents. These circumstances make their study time very minimal even none at all. These kinds of things ultimately lead to a slow development in the ability of students in any learning from elementary to high school level, especially about language learning which is related to writing and reading skills.

Researchers ultimately conclude that a slow ability in these two language skills will have an effect on the bilingual and multilingual capabilities of the Pontas Villages. Let alone to understand and be able to use a second or third language, for learning to read and write did not make it as important. The existence of social factors that have become deeply rooted in the culture in their 
lives have contributed greatly to their inaction in learning other languages besides the Indonesian language they are forced to master as an official language of instruction.

Unlike the community in the other four regions of SindangJawa, the second or third language and the mastery of the Indonesian language, multilingual capability is considered as an important science acquisition for their survival. Coupled with the social factors that exist, began to develop in a positive direction that encourages his children to advance in the field of education.

According to Mr. DuanMuwardi, the community in RW 2, 3, 4, and 5 is categorized as a more educated society than the people of Pontas Village. This is also what the researchers say allows for a boost in their community in acquiring better linguistic knowledge, so that they can be categorized as active dwibahasawan even have the ability as multilingual. Therefore the authors provide an assessment to the community in RW 2, 3, 4, and 5 as a linguistic society at the level of bilingual active actively with their linguistic abilities that not only understands even fluently speaking for a second language, and a third language within the scope of SindangJawa Village. Although if heard by researchers, people outside the village of Pontas still speak Sundanese with dialect kejawa-jawaan and speak Javanese with dialect kesunda-sundaan.

\section{CONCLUSION}

The two types of communities in SindangJawa Cirebon Village that is between RW 1 (KampungPontas) community with RW 2, 3, 4, and 5, agreed to express the real reason why people from KampungPontas who speak in Javanese language as their mother tongue have difficultiesinusing Sundanese, unlike those in RW 2, 3, 4, and 5 that are generally fluent in Javanese. In the opinion of both people said that the words in Sundanese often use the phoneme "eu", which makes people say Pontas that in fact the Javanese become lazy and difficult in memapalkanSundanese language.

The bilingual and multilingual characteristics in SindangJawa give birth to a code, code mixing, diglossia, parol, dialect and distinctive local idiolects. The code transfer other than an adult like Pak Juhari, was done by the children of KampungPontas. When talking with their friends they use the Javanese language, but when spoken to in Indonesian, they change the conversation into Indonesian. This kind of incident is not much different from the children in SindangJawa village in RW 2, 3, 4, and 5, although in this region, their children master the Javanese language.

Other information mentioned that the students in SindangJawa Junior High School who came from Pontas Village have a culture that has been passed down from their parents that children since childhood should help the family economy. Many of them in elementary school age must help their parents to sell, go to the fields, or work on their parents' business such as furniture crafts. It is these circumstances that ultimately make their learning time very minimal or even absent. These kinds of things ultimately lead to a slow development in the ability of students in any learning from elementary to high school level, especially language learning of students who are concerned with writing and reading skills.

Researcher concludes that the slow ability in these two language skills ultimately influences the level of bilingual and multilingual capabilities of the community in Pontas Village. Let alone to understand and be able to use a second or third language, to read and write bukab important things to learn in their lives. The existence of social factors that have been entrenched for a long time in their lives has contributed greatly to the slowness in learning other languages besides Indonesian.

In contrast to the community in the other four areas of SindangJawa, in addition to a fairly good mastery of Indonesian language, multilingual capability is regarded as an important science acquisition for their survival. It also added that social factors exist, evolving in a positive direction. A culture that encourages more children in the field of education is visible. 


\section{REFERENCES}

Chaer, Abdul \&Agustina, Leoni (2004) Sosiolinguistik Perkenalan Awal. Jakarta: PenerbitRinekaCipta.

Mckay, Sandra Lee \&Hornberger, Nancy (2009) Sociolinguistics and Language Teaching. San Fransisco: Cambridge University Press.

Poerwadarminta, W.J.S (2006) KamusUmumBahasa Indonesia. Jakarta: BalaiPustaka.

Rakhmat, Jalaluddin (1991) Metode Penelitian Komunikasi, Bandung: Remaja Rosdakarya.

Rusyana, Yus (1988) PerihalKedwibahasaan (Bilingualisme). Bandung: FPS IKIP Bandung.

Suherli (2007) Menulis Karangan Ilmiah, Depok: Arya Duta.

Syamsuddin \& Damaianti, Vismaia S. (2006) Metode Penelitian Pendidikan Bahasa, Bandung: Remaja Rosdakarya.

Jurnal Kajian Komunikasi. Hedi Heryadi, Hana Silvana. Komunikasi Antarbudaya Dalam Masyarakat Multikultur (Studi Tentang Adaptasi Masyarakat Migran Sunda Di Desa Imigrasi Permu Kecamatan Kepahiang Provinsi Bengkulu).Vol.1 No.1 Juni 2013.Hlm. 95-108

Jurnal Gramatika. Daman Huri.Geografi Variasi Bahasa Di Bagian Utara Karawang Jawa Barat. http://dx.doi.org/10.22202/JG.2017.V3i2.2159 